\section{Moisture Affects Cowpea and Okra Seed Emergence and -Growth at Low Temperatures}

\author{
Lurline Marsh' \\ Department of Agriculture, Natural Resources, and Home Economics, \\ Lincoln University, Jefferson City, MO 65102-0029
}

Additional index words. Abelmoschus esculentus, Vigna unguiculata, seed germination, vegetable crops

\begin{abstract}
The effect of moisture content on the emergence and development of 'Pinkeye Purple Hull' and MN 13 cowpea [Vigna unguiculata (L.) Walp.] and 'Clemson Spineless' okra [Abelmoschus esculentus (L.) Moench] seeds was investigated in a 3-year field study. Moisture content, ranging from $8 \%$ to $52 \%$, was obtained by combining seeds, vermiculite, and varying volumes of water in sealed polyethylene packets and incubating them at 22C for 3 days. High moisture promoted the emergence of $\mathrm{MN} 13$, did not significantly affect that of 'Pinkeye Purple Hull', and decreased that of 'Clemson Spineless' seeds. Percent seed emergence 22 days after planting averaged $17 \%$ for 'Clemson Spineless' and $15 \%$ for 'Pinkeye Purple Hull' seeds, but was $44 \%$ for MN 13. High moisture generally promoted early harvest of MN 13 and increased root dry weight but did not affect freshpod yield significantly.
\end{abstract}

Moisture plays an important role in seed germination and emergence. Early in this century, Kidd and West (1918) hydrated bean seeds by soaking them in water. They reported increased germination and growth of soaked broad bean seeds (Vicia faba L.) and increased germination but decreased growth of dwarf beans (Phaseolus vulgaris L.). Seeds can be hydrated or conditioned via either the liquid or vapor phase and brought to an equilibrium water content below which germination is permitted (Hegarty, 1978).

Since the reports of Kidd and West, several studies have shown that increased moisture can improve seed germination and emergence of diverse beans and other crops (Bennett and Waters, 1984; Christiansen, 1968; Khan et al., 1992; Obendorf and Hobbs, 1970; Phillips and Youngman, 1971; Roos and Manalo, 1976; Wilson and Trawatha, 1991). Lima bean (Phaseolus lunatus L.) seeds emerged better at low soil temperatures if moisture was at least 12\% (Bennett and Waters, 1984). More snap bean (P. vrdgaris) seeds with $12 \%$ moisture emerged than those with lower moisture, particularly at <10C (Roos and Manalo, 1976). More soybean [Glycine $\max ($ L.) Merr.] seeds

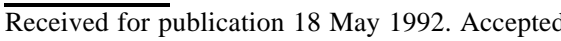
for publication 11 Mar. 1993. Lincoln Univ. Agricultural Experiment Station Journal paper no. A6-226-92. Trade names are mentioned with the understanding that no discrimination is intended and no endorsement by us or Lincoln Univ. is implied. Research was supported in part by U.S. Dept. of Agriculture-Cooperative State Research Service funds allocated to the Lincoln Univ. AgriculturalExperimentStation. The cost of publishing this paper was defrayed in part by the payment of page charges. Under postal regulations, this paper therefore must be hereby marked advertisement solely to indicate this fact.

1 Associate Professor. with $16 \%$ moisture survived at $5 \mathrm{C}$ than those with 6\% moisture (Obendorf and Hobbs, 1970). The work of Wilson and Trawatha (1991) further showed that irrigation after planting increased seed emergence by $15 \%$ to $30 \%$ for seeds with 70 to $140 \mathrm{~g} \mathrm{H}_{2} \mathrm{O} / \mathrm{kg}$, while pre-irrigation had no effect.

Without hydration, seeds of chilling-sensitive crops, such as cowpeas and okra, experience imbibitional injury at low temperatures. As described by Christiansen (1978), chillingsensitive plants are those injured by temperatures between 0 and 10C. Based on the successful results of seed hydration with other crops, hydration may improve cowpea and okra seed germination and emergence at low temperatures. Improved seed emergence allows early planting and harvesting, thus preventing late-season environmental stresses, such as drought.

Few reports are available on the effects of moisture on cowpea and okra seed emergence in the field. Baxter and Waters ( 1986) reported that a hydrophilic polymer seed coating deleteriously affected cowpea seed germination and seedling development in the field. A higher percentage of okra seeds with $9 \%$ moisture germinated than those with $3 \%$ moisture in rolled towel tests at 20/30C (Standifer et al., 1989). At low temperatures, Singh et al. (1983) various volumes of water in the medium. reported that okra seeds preconditioned with polyethylene glycol 600 at -5.0 or -7.5 bars germinated better at $10 / 15 \mathrm{C}$ than at constant $15 \mathrm{C}$. The study reported here was conducted to determine the effect of increased moisture content on the emergence and growth of cowpea and okra seeds when planted early into cold soil.

The effect of moisture content on the emergence and development of MN 13 and 'Pinkeye Purple Hull' cowpea and 'Clemson Spineless' okra seeds was studied with seeds that were planted in the field on 18 Apr. 1986, 24 Apr. 1987, and 15 Apr. 1988. Four moisture levels were attained for each crop by incubating seeds with vermiculite grade 3 containing various amounts of water. Standard germination in petri plates at $27 \mathrm{C}$ was at least $90 \%$ for each crop. Vermiculite $(60 \mathrm{~g})$ and seeds $(20 \mathrm{~g})$ were mixed in polyethylene zipper seal bags $(46 \times 23 \mathrm{~cm})$. Moisture content was adjusted by adding $0,25,50$, or $100 \mathrm{ml}$ of water to each bag. The bags were closed and the contents were mixed thoroughly and incubated at $22 \mathrm{C}$ for 3 days. Radicles $\approx 5 \mathrm{~mm}$ long emerged in $5 \%$ to $10 \%$ of the seeds of the crops incubated in the 100-ml water-vermiculite mixture; these seeds were discarded. Moisture content of the remaining nongerminated seeds in the $100-\mathrm{ml}$ water-vermiculite mixture and the other three treatments was determined based on oven dry weight using the International Seed Testing Association's procedures for oily seeds (okra) and nonoily seeds (cowpea) (Hanson, 1985). The adjusted moisture percentages ranged about four-fold (Table 1). Seeds were handplanted in the field $4 \mathrm{~cm}$ deep at Lincoln Univ.'s Greenberry Farm, Jefferson City, Mo. (soil type Elk silt loam Ultic Hapladult, $\mathrm{pH}$ 6.5). The seeds were spaced $\approx 5 \mathrm{~cm}$ apart in three-row, 4.5 -m-long plots with $0.9 \mathrm{~m}$ between rows. Okra seeds were planted in a randomized complete-block design with three replications and four moisture level treatments. Cowpea seeds were planted in a randomized complete-block design with two cowpea types and four moisture level treatments arranged in a split plot. The main plot was cowpea type and there were three replications.

Emerged seedlings were counted and the numbers were recorded at 2-day intervals up to 22 days after planting. A seedling was considered emerged when the hypocotyl hook was visible above the soil's surface. At 28 days after planting, cowpea plants were thinned to $10 \mathrm{~cm}$ apart. No further growth data were recorded for okra beyond seedling emergence because of the poor stands. Data were recorded for cowpeas on days to frost bloom,

Table 1. Mean moisture content over 3 years for cowpea and okra seeds incubated at 22C for 3 days with

\begin{tabular}{|c|c|c|c|}
\hline \multirow{3}{*}{$\begin{array}{l}\text { Vol of } \\
\text { water }^{2} \\
\text { (ml) }\end{array}$} & \multicolumn{3}{|c|}{ Moisture content $(\%)$} \\
\hline & \multicolumn{2}{|r|}{ Cowpea } & \multirow{2}{*}{$\frac{\text { Okra }}{\text { Clemson Spineless }}$} \\
\hline & $\mathrm{MN} 13$ & Pinkeye Purple Hull & \\
\hline 0 & 12 & 12 & 8 \\
\hline 25 & 31 & 38 & 26 \\
\hline 50 & 39 & 40 & 33 \\
\hline 100 & 46 & 48 & 35 \\
\hline
\end{tabular}

${ }^{\mathrm{z}}$ Each volume was mixed with $60 \mathrm{~g}$ vermiculite and $20 \mathrm{~g}$ seed for incubation. 
first fresh-pod harvest, shoot length, length of longest root, number of roots, root and shoot dry weights per plant at final fresh harvest, total fresh-pod weight per plant, pod length, number of seeds per pod, and weight of 25 seeds. Except for days to flowering and freshpod harvest, no further data were recorded for 'Pinkeye Purple Hull' in 1988 because emergence was very low. Soil temperatures at night remained $<5 \mathrm{C}$ for some of the first 22 days after planting in 1988 but not in the two preceding years. Total fresh-pod harvest was collected from five plants in the center row and consisted of five to seven harvests over 3 to 4 weeks. Pod length and number of seeds per pod were measured on five pods at each harvest. The shoot and root characteristics were determined for the five plants from the center row after the final fresh-pod harvest.

Plants were irrigated by a sprinkler $(\approx 15$ $\mathrm{mm}$ water per application) when needed and insects were controlled with sprays of 0,0 -diethyl 0 -[2-isopropyl-4 -methyl-6 pyrimidinyl] phosphorothioate (diazinon). Soil temperatures at $8 \mathrm{~cm}$ deep and air temperatures in the plot were monitored by remote three-point thermographs (Weathertronic; Qualimetric, Sacramento, Calif.) and hygrothermographs (Cole Partner, Chicago), respectively (Figs. 1-3). Combined rainfall and irrigation data also were recorded (Figs. 1-3).

The okra seeds in the control treatment had a slightly lower moisture content than the two cowpea types (Table 1). Likewise, the highest moisture content obtained for okra seeds was $\approx 10 \%$ lower than that for cowpeas. The lower percentage moisture content for okra perhaps is due to decreased imbibition because of its hard seedcoat or because of differences in seed storage compared to cowpea (Baxter and Waters, 1986; Hanson, 1985; Vertucci, 1989).

Analysis of variance for cowpea emergence for the first 22 days was done separately for years because the type $\mathrm{x}$ moisture $\mathrm{x}$ year $\mathrm{x}$ emergence time interaction was significant. The two cowpea types responded differently in their emergence (Table 2). In all cases, more MN 13 seeds emerged than 'Pinkeye Purple Hull' (Figs. 4-6). A consistent linear emergence response was found for MN 13 each year, while its quadratic and cubic responses and the linear, quadratic, and cubic response for 'Pinkeye Purple Hull' varied. The emergence of 'Pinkeye Purple Hull' seeds with all moisture levels generally was similar during the first 22 days. MN 13 maybe more tolerant to cold soils than 'Pinkeye Purple Hull', perhaps due to early seed development under colder conditions or greater sensitivity of 'Pinkeye Purple Hull' to pathogens in the cold soil. Significantly more MN 13 seeds with $33 \%$ and $40 \%$ moisture in 1987 and $44 \%$ and $50 \%$ moisture in 1988 emerged than those with $11 \%$ moisture 3 weeks after planting.

During the 1987 and 1988 studies (Figs. 5 and 6), more $\mathrm{MN} 13$ seeds emerged on day 22 for some moisture levels $>11 \%$. However, this trend was the reverse of that in 1986 (Fig. 4), when significantly more seeds with $14 \%$ moisture emerged than those with higher moisture

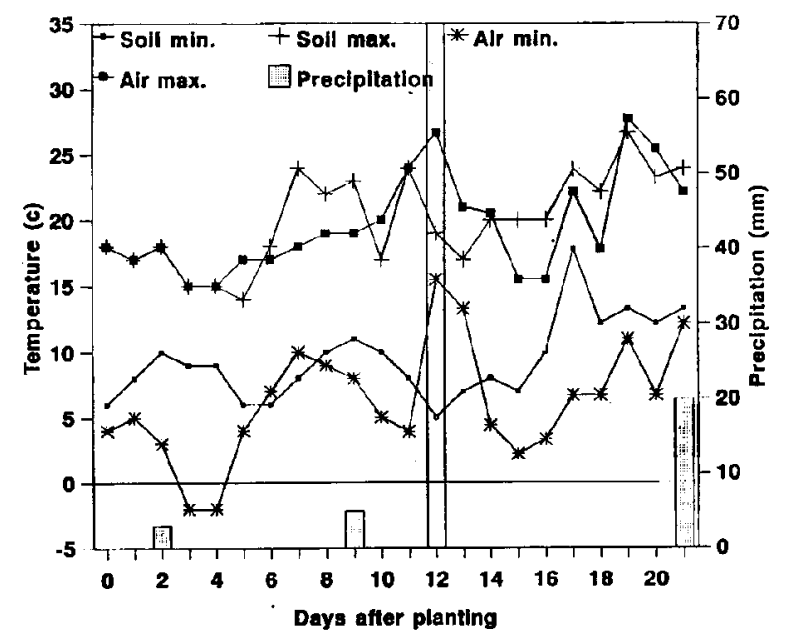

Fig. 1. Daily maximum and minimum temperatures and precipitation during seed emergence in 1986.

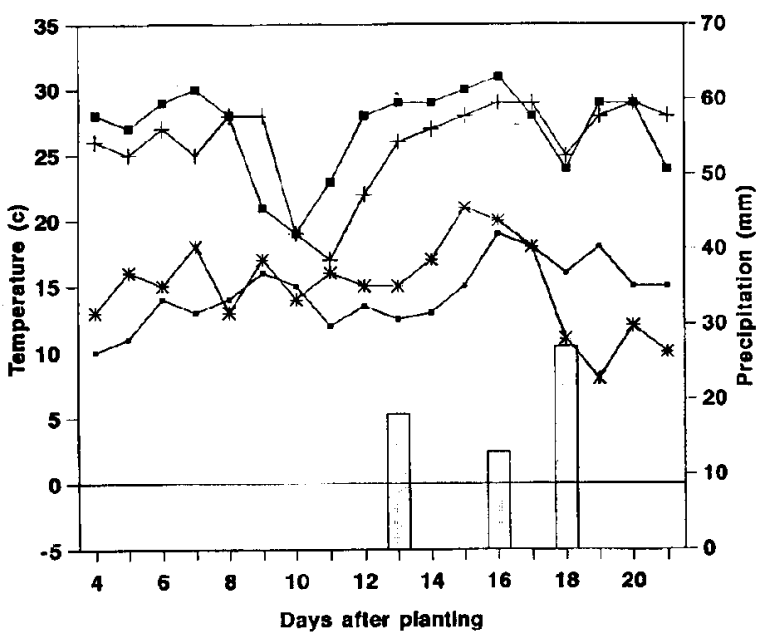

Fig. 2. Daily maximum and minimum temperatures and precipitation during seed emergence in 1987.

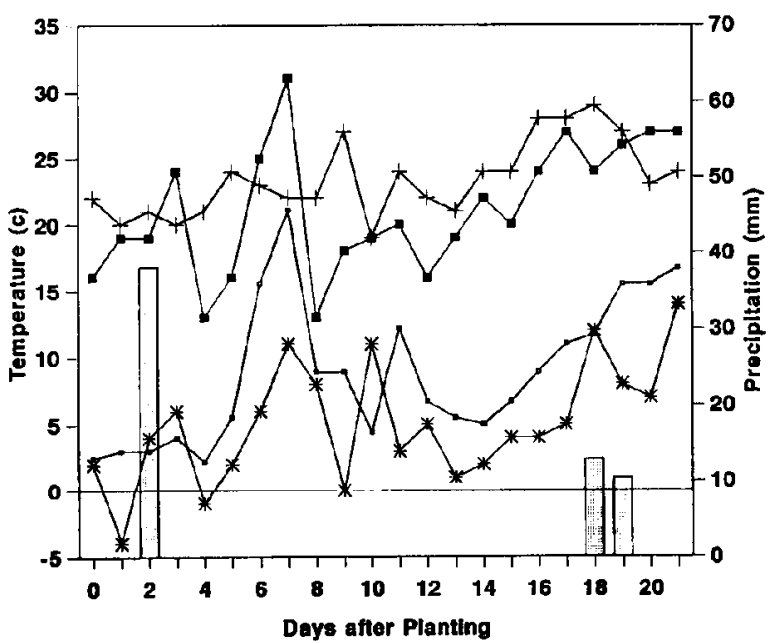

Fig. 3. Daily maximum and minimum temperatures and precipitation during seed emergence in 1988.

Table 2. Field seed emergence response of two cowpea types (C) to moisture (M) and time (T).

\begin{tabular}{|c|c|c|c|c|c|}
\hline Year & $\begin{array}{c}\text { Moisture } \\
\text { (M) }\end{array}$ & $\begin{array}{c}\text { Cowpea } \\
\text { type } \\
\text { (C) }\end{array}$ & $\mathrm{C} \times \mathrm{M}$ & $M \times T$ & $\mathrm{C} \times \mathrm{M} \times \mathrm{T}$ \\
\hline 1986 & NS & $* *$ & NS & $* *$ & $* *$ \\
\hline 1987 & NS & $* *$ & NS & NS & NS \\
\hline 1988 & NS & $* *$ & NS & Ǹs & NS \\
\hline
\end{tabular}

ws. "Nonsignificant or significant at $P \leq 0.01$, respectively. 


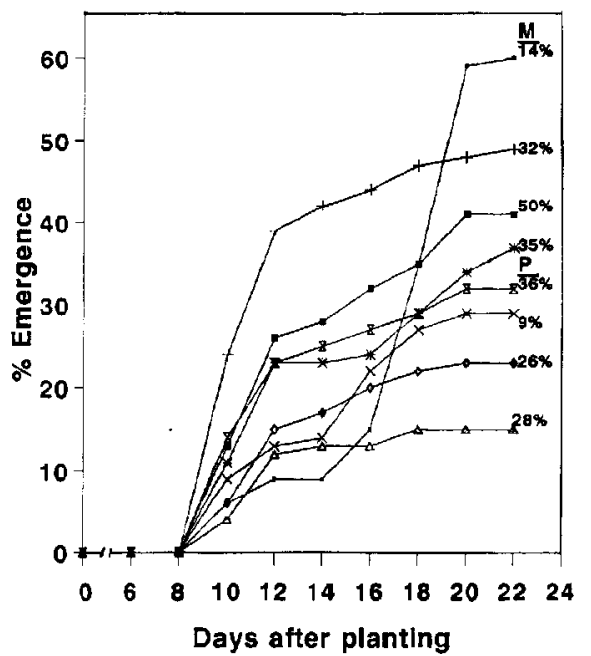

Fig. 4. Effect of moisture content on seed emergence of two cowpea types in 1986. $\mathrm{M}=\mathrm{MN} 13 ; \mathrm{P}=$ 'Pinkeye Purple Hull'. Treatment effects $(\mathrm{L}=$ linear, $\mathrm{Q}=$ quadratic, $\mathrm{C}=$ cubic) were nonsignificant (NS) or significant at $P \leq 0.05$ or 0.01 . All $\mathrm{L}$ effects were significant at $P \leq 0.01$. Q effects were significant at $P \leq 0.01$ for $14 \% \mathrm{M}, 32 \% \mathrm{M}$, $50 \% \mathrm{M}$, and $36 \% \mathrm{P} ; P 0.05$ for $26 \% \mathrm{P}$; and NS for $35 \% \mathrm{M}, 9 \% \mathrm{P}$, and $28 \% \mathrm{P}$. All C effects were NS.

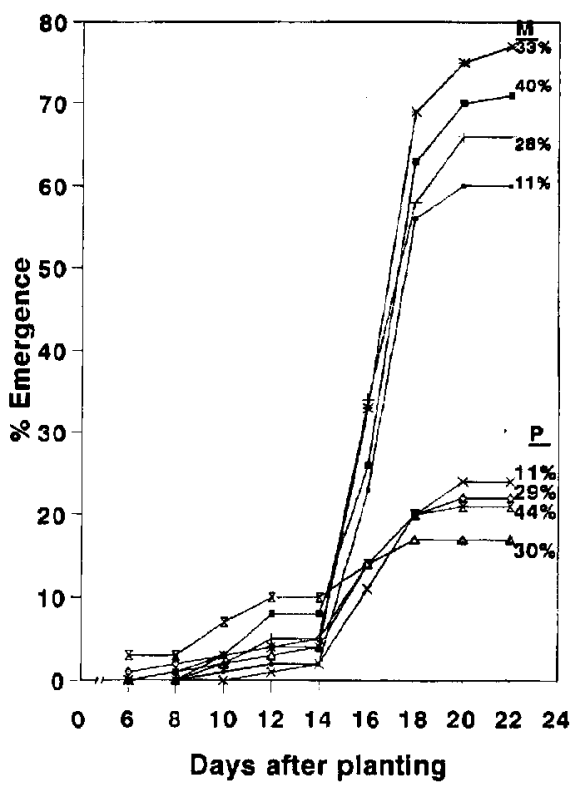

Fig. 5. Effect of moisture content on seed emergence of two cowpea types in 1987. $\mathrm{M}=\mathrm{MN} 13 ; \mathrm{P}=$ 'Pinkeye Purple Hull'. Treatment effects $(\mathrm{L}=$ linear, $\mathrm{Q}=$ quadratic, $\mathrm{C}=$ cubic) were nonsignificant (NS) or significant at $P \leq 0.05$ or 0.01 . All L effects were significant at $P \leq 0.01$. Q effects for all levels of $\mathrm{M}$ and $11 \% \mathrm{P}$ were significant at $P \leq 0.01$ and Ns for $29 \% \mathrm{P}, 30 \% \mathrm{P}$, and $44 \% \mathrm{P}$. C effects were significant at $P \leq 0.01$ for all levels of $\mathrm{M}$ and NS for all levels of $\mathrm{P}$.

from day 20 to 22 . In contrast, more seeds with higher moisture emerged in 1986 than those with $14 \%$ moisture before day 16 . Increased emergence of MN 13 seeds by increased moisture content before planting concurs with previous reports of Roos and Manalo (1976) for snap beans and Bennett and Waters (1984) for lima beans. In this study, emergence of 'Pinkeye Purple Hull' seeds was not promoted by

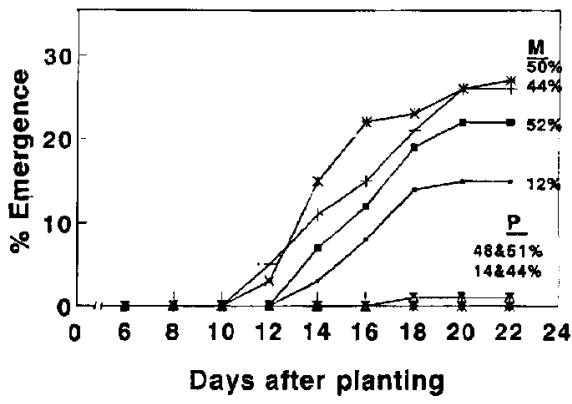

Fig. 6. Effect of moisture content on seed emergence of two cowpea types in 1988. $\mathrm{M}=\mathrm{MN} 13 ; \mathrm{P}=$ 'Pinkeye purple Hull'. Treatment effects $\left(\mathrm{T}_{-}\right.$. linear, $\mathrm{Q}=$ quadratic, $\mathrm{C}$. cubic) were nonsignificant (NS) or significant at $P 0.05$ or 0.01 , L effects for all $\mathrm{M}$ were significant at $P 0.01$ and NS for $\mathrm{P}$. All Q effects were Ns. C effects were significant at $P \leq 0.01$ for $50 \% \mathrm{M}, P 0.05$ for $44 \%$ and $52 \%$ $\mathrm{M}$, and Ns for $12 \% \mathrm{M}$ and all levels of $\mathrm{P}$.

increasing moisture content and was generally lower than that of MN 13 seeds.

A combined analysis of variance over years was done for okra because the moisture $\mathrm{x}$ year $x$ emergence time interaction was nonsignificant. Emergence 21 days after planting averaged $<30 \%$ during the 3 years (Fig. 7). As moisture content increased from $8 \%$ to $35 \%$, emergence decreased. The different responses of cowpea and okra may be due to the microstructural differences in the seeds of these two species. Seed microstructure (which is a function of seed morphology) composition, water content, and temperature play a major role in water diffusion and seed imbibition (Vertucci, 1989). Okra seeds have thick seedcoats and contain more lipids than cowpea seeds. These factors can slow seed hydration. If okra seeds were hydrated to the highest moisture level attained for cowpeas (52\%), 35\% to 5270 moisture content might improve seed emergence in the field. Standifer et al. (1989) and Sing et al. ( 1983) showed that increased moisture content promoted seed germination at controlled low temperatures when moisture was regulated also. In this field study, field moisture was nonuniformly distributed; irrigation immediately after seeding, such as that used by Wilson and Trawatha (1991), might have been beneficial. Preliminary germination tests on small samples of okra seeds in petri plates lined with filter paper showed that seeds with 3570 moisture germinated after 14 days at $10 \mathrm{C}$, while those with $8 \%$ moisture did not.

Cowpea growth and yield data for the 3

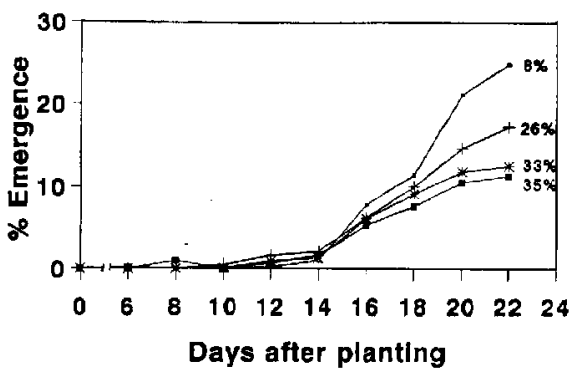

Fig. 7. Effect of moisture content on seed emergence of 'Clemson Spineless' okra during 3 years. Treatment effects $(\mathrm{L}=$ linear, $\mathrm{Q}=$ quadratic, $\mathrm{C}$ $=$ cubic) were nonsignificant (NS) or significant at $P \leq 0.05$ or 0.01 . L effects were significant at $P 0.01$ for all levels. Q effects were significant at $P \leq 0.01$ for $8 \%, P 0.05$ for $26 \%$, and Ns for $33 \%$ and $35 \%$. C effects were significant at $P \leq$ 0.05 for $8 \%$ and $33 \%$ and $\mathrm{Ns}$ for $26 \%$ and $35 \%$.

years were pooled for analysis because the year $\mathrm{x}$ moisture $\mathrm{x}$ genotype interaction was nonsignificant. Although increased moisture content generally promoted earlier yields from MN 13 plants, increased moisture content did not significantly affect MN 13 yield (Table 3) and affected 'Pinkeye Purple Hull' yield inconsistently (days to flowering, 61 to 64 ; days to harvest, 80 ; yield/plant 0.34 to $0.38 \mathrm{~kg}$; pod length, 18.0 to $18.4 \mathrm{~cm}$; weight of 25 seeds, 8.6 to $8.9 \mathrm{~g}$ ). The lack of yield response to moisture treatments, despite improved seed emergence in the case of MN 13, is comparable to Bennett and Waters' results with lima bean (1984). They reported a lesser effect of initial moisture content on yield than on seed emergence. MN 13 plants grown from seeds with high moisture content also had higher root dry weight, but the number of roots and shoot dry weight were not affected significantly (Table $4)$. None of these variables responded significant y for' Pinkeye Purple Hull'. The average number of seeds per pod for the two cowpea types was 12 and was not influenced by moisture. Shoot and root lengths did not differ significantly for either type.

These results suggest that, in the field in cold soil, $12 \%$ to $47 \%$ moisture may improve cowpea seed emergence, while $<35 \%$ moisture improves that of okra. Further, the two cowpea types responded differently to increased moisture. Increased moisture content promoted MN 13 seed emergence but was ineffective with 'Pinkeye Purple Hull'. Increased moisture content up to $35 \%$ decreased okra seed emergence. Increased moisture con-

Table 3. Effect of moisture content of MN 13 cowpea seeds on yield characteristics.

\begin{tabular}{|c|c|c|c|c|c|}
\hline $\begin{array}{l}\text { Moisture } \\
(\%)\end{array}$ & $\begin{array}{l}\text { Days to } \\
\text { flowering }\end{array}$ & $\begin{array}{l}\text { Days to } \\
\text { harvest }\end{array}$ & $\begin{array}{c}\text { Fresh } \\
\text { pod yield/ } \\
\text { plant (kg) }\end{array}$ & $\begin{array}{l}\text { Pod } \\
\text { length } \\
(\mathrm{cm})\end{array}$ & $\begin{array}{c}\text { Wt of } \\
25 \text { seeds } \\
(\mathrm{g})\end{array}$ \\
\hline 12 & 57 & 72 & 0.10 & 18.6 & 9.0 \\
\hline 35 & 53 & 70 & 0.11 & 18.2 & 7.3 \\
\hline 39 & 56 & 70 & 0.12 & 18.5 & 8.9 \\
\hline 47 & 52 & 70 & 0.11 & 18.8 & 9.0 \\
\hline \multicolumn{6}{|l|}{ Effects } \\
\hline Linear & NS & $* *$ & NS & NS & NS \\
\hline Quadratic & NS & NS & NS & NS & $*$ \\
\hline Cubic & NS & NS & NS & NS & NS \\
\hline
\end{tabular}

$\overline{\text { Ns,*,*** }} \quad$ Nonsignificant or significant at $P 0.05$ or 0.01 , respectively. 
Table 4. Effect of moisture content of MN 13 cowpea seeds on root count and root and shoot dry weights (per plant).

\begin{tabular}{lccc}
\hline Moisture & $\begin{array}{c}\text { Root } \\
(\%)\end{array}$ & $\begin{array}{c}\text { Root } \\
\text { dry wt } \\
(\mathrm{g})\end{array}$ & $\begin{array}{c}\text { Shoot } \\
\text { dry wt } \\
(\mathrm{g})\end{array}$ \\
\hline 12 & 13 & 3.3 & 48.8 \\
35 & 17 & 7.2 & 56.1 \\
39 & 15 & 4.6 & 65.0 \\
47 & 15 & 6.1 & 61.0 \\
Effects & & $*$ & NS \\
Linear & NS & NS & NS \\
Q u a d r a tic & N S & $*$ & NS \\
Cubic & NS & & \\
\hline
\end{tabular}

"'Nonsignificant or significant at $P \leq 0.05$. respectively.

tent promoted earlier harvest and higher root dry weight for cowpeas.

\section{Literature Cited}

Baxter, L. and L. Waters, Jr. 1986. Effect of hydrophilic polymer seed coating on the field performance of sweet corn and cowpea. J. Amer. Soc. Hort. Sci. 111:31-34.
Bennett, M.A. and L. Waters, Jr. 1984. Influence of seed moisture on lima bean stand establishment and growth. J. Amer. Soc. Hort. Sci. 109:623626.

Christianson, M.N. 1968. Induction and prevention of chilling injury to radicle tips of imbibing cotton seed. Plant Physiol. 43:743-746.

Christiansen, M.N. 1978. The physiology of plant tolerance to temperature extremes, p. 173-19 1 . In: J.A. Jung (cd.). The physiology of plant tolerance to temperature extremes. Crop Sci. Soc. Amer., Madison, Wis. Amer. Soc. Agron. Spec. Publ. 32

Hanson, J. 1985. Determination of seed moisture content, p. 30-38. In: Procedures for handling seeds in genebanks. Intl. Board Plant Genet. Resources, Secretariat, Rome.

Hegarty, T.W. 1978. The physiology of seed hydration and dehydration and the relation ,between water stress and the controls of germination: A review. Plant Cell Environ. 1: 101-1 19.

Khan, A.A., J.D. Maguire, G.S. Abawi, and S. Ilyas. 1992. Matriconditioning of vegetable seeds to improve stand establishment in early field plantings. J. Amer. Soc. Hort. Sci. 117:41-47.

Kidd, F. and C. West. 1918. Physiological pre-determination: The influence of the physi- ological condition of the seed upon the course of subsequent growth and upon the yield. Ann. Applied Biol. 5:1-11.

Obendorf, R.L. and P.R. Hobbs. 1970. Effect of seed moisture on temperature sensitivity y during imbibition of soybean. Crop Sci. 10:563-566.

Phillips, J.C. and V.E. Youngman. 1971. Effects of initial seed moisture content on emergence and yield of grain sorghum. Crop Sci. 11:354-357.

Roos, E.E. and J.R. Manalo. 1976. Effect of initial seed moisture on snap bean emergence from cold soil. J. Amer. Soc. Hort. Sci. 101:321-324.

Singh, H., T.J. Orton, and K. Haertridgeesh. 1983. Standardization of osmo-conditioning of okra seed. Indian J. Agr. Sci. 53:24-26.

Standifer, L. C., P.W. Wilson, and A. Drummond. 1989. The effects of seed moisture content on hard seededness and germination of four cultivars of okra (Abelmoschus esculentus). Plant Var. \& Seeds 2:149-154.

Vertucci, C.W. 1989. The kinetics of seed imbibition: Controlling factors and relevance to seedling vigor, p. 93-1 15. In: Seed moisture. Crop Sci. Soc. Amer., Madison, Wis. Spec. Publ. 14.

Wilson, D.O., Jr., and S.E. Trawatha. 1991. Enhancement of bean emergence by seed moisturization. Crop Sci. 31:1648-1651. 